\title{
From the Perspective of Eternity
}

\author{
Robin McAllister \\ Sacred Heart University, Fairfield, Connecticut, USA
}

\begin{abstract}
This is a partial history of the literary topos "sub specie aeternitatis". The Latin phrase means "from the perspective of eternity". Eternity is the way God sees the universe, not as a succession of moments in time from past, to present, to future, but as a simultaneous present which includes the past and future as if they are already and always present. This temporal simultaneity is accompanied by a spatial totality and simultaneity. In both Chaucer and Dante the protagonist ends life's wanderings and struggles by being carried up into the heavens and looking back on earth from the point of view of eternity. Their literary source is Macrobius' Commentary on the Dream of Scipio and Boethius' The Consolation of Philosophy. The vision results in epistemological transformation that provides consolation or "contemptus mundi", the rejection of earthly concerns. The "sub specie aeternitatis" vision is both a revelation of the nature of the universe, time, and the protagonist's place in them and a disillusionment that radically changes the protagonist's understanding. The work of literature and the reading of it are potentially transformational. For the pagan lover Toilus in Chaucer's Troilus and Criseyde the "sub specie aeternitatis" vision results in religious conversion as well as epistemological transformation. Boethius, whom Chaucer translated, offers an analogue to the vision in the way humans perceive a sphere through their senses and reason. Dante's version of the vision in Paradiso xxxiii is the most famous literary example as the protagonist's vision merges with the vision of God as an intense ray of light. The conversion and consolation associated with the "sub specie aeternitatis” vision takes cosmic dimension in Dante. A modern example is Jorge Luis Borges' parody of Dante in his story "The Aleph" where a satiric vision takes place not in the heavens but in the basement of the house in Buenos Aires. In Cervantes’ Don Quixote the “sub specie aeternitatis” trope is present by its deliberate omission, and yet performs the functions of epistemological conversion, transformation, and consolation in Don Quixote's death. One brief sleep and Don Quixote passes from dreaming (in Borges' sense of the word) a reality from the fantasy of his books of chivalry to a true reality, similar to the conversion Troilus experiences from the sorrow of love to the pure felicity of heaven. With Don Quixote and the realist novel the "sub specie aeternitatis" vision may seem bound for extinction, at least with its cosmological apparatus of heavenly spheres, but it finds new form in the ending of Gabriel Garcia Marquez's One Hundred Years of Solitude. The final reading of Melquiades's parchments reveals that the sequential events of the novel exist as if in a simultaneous moment, like God's eternity, embracing all time and space in one, before the vision vanishes forever.
\end{abstract}

Keywords: eternity, Chaucer, Boethius, Cervantes

\section{Introduction}

Certain works of medieval literature in which the protagonist ends his wanderings, struggles, and passions by being carried up into the heavens and looking back down on the earth from the perspective or view point of

Robin McAllister, Associate Professor, Department of English, Sacred Heart University. 
eternity conclude with the literary topos, "sub specie aeternitatis" (Sinclair, 1961, p. 490). The Latin phrase means "from the perspective of eternity". Eternity for Boethius, St. Thomas, and Dante is the way in which God sees the universe, not as a succession of moments in time from past, to present, to future, but as a simultaneous present which includes the past and future as if they were already and always present. This temporal simultaneity is accompanied by a spatial totality and simultaneity. The universe seen as God sees it is not just simultaneous present, a dimensionless moment, but a simultaneously presence of the totality of the universe both its entire structure and each and every detail, part, and accident. Temporal present, with a " $\mathrm{t}$ ", and spatial presence, with a "c”, constitute the simultaneity accessible through "sub specie aeternitatis" vision.

For medieval writers like Dante and Chaucer the topos or motif, was familiar from two of the most influential sources of Platonic philosophy available to them, Macrobius' Commentary on the Dream of Scipio and Boethius' The Consolation of Philosophy, from the fourth and fifth Centuries A.D., respectively, and their concepts of time, eternity, and the transformational function of the "sub specie aeternitatis" vision reflect a Christian Platonism. Underlying the Platonic search for the reality behind appearances and the effort to distinguish between the true good and false goods that mislead us to our sorrow is the archetypal pattern of narrative we find in quest romance, where a protagonist goes on a journey full of adventures that test and tempt the searcher until a crucial encounter with life and death consequences. If he or she survives, the protagonist is changed or transformed in a significant way. What crucial encounter could be more life threatening and life enhancing than the rapture or snatching up of the mind and soul out of this world to look back on life from the perspective of the heavens? The vision always results in an epistemological transformation that implies a consolation, a revelation, within the total fulfillment of the "sub specie aeternitatis" vision, which cancels previous sorrow and ignorance in life. Along with epistemological transformation and consolation is "contemptus mundi," the retraction or rejection of earthly concerns for false and partial goods within the context of cosmic blessedness. The "sub specie aeternitatis" vision is therefore both a revelation, a revelation of the nature of the universe and time and the protagonists place in them, and a disenchantment or disillusionment that radically changes the understanding of life. The reading of such a work of literature is also potentially transformative. The reader will come away from it with a perspective of self and reality changed in a significant way.

\section{Chaucer's Troilus and Criseyde}

Macrobius, whom we have mentioned, wrote a kind of encyclopedia of Platonic cosmology and dream interpretation known as the Commentary on the Dream of Scipio. The Roman general of that name is taken in dream up to the highest heaven of the Fixed Stars where he looks back down on earth. He is guided by the soul of his ancestor, also named Scipio, who wants to inspire Scipio to pursue his Roman destiny by showing him the eternal place destined for souls after death, the insignificance of human life and history in the context of the heavens, and the consolation of sorrow and sacrifice in the eternal life of the soul. His work provides the model for Chaucer in the 14th century.

Contemptus mundi, consolation, conversion, and retraction are all part of Troilus' "sub specie aeternitatis" vision at the end of Chaucer's Troilus and Criseyde. Chaucer writes: "Go, litel bok, go, litel myn tragedye, / Ther God thi makere yet, er that he dye, / So sende might to make in som comedye!” (Robinson, 1957, p. 479), in Dante's sense of a story that begins in sorrow and ends in happiness. Troilus cannot give up his love for Criseyde, even after he finds proof of her betrayal of him for the love of a Greek warrior in a broach pinned to 
Diomedes' cloak. In despair Troilus seeks death in battle, a death already prefigured in the frescoes of Juno's Temple in Carthage that Aeneas gazed upon before supplicating Dido's love and help in the Aeneid, like Troilus and Criseyde another story of love and betrayal and the probable source for the legend of Troilus and Criseyde in late antiquity. Slain by Achilles, Troilus' soul leaves the body on the battlefield before Troy, and, as in Scipio's dream, mounts up to the hollow eighth sphere where he hears the divine harmony of the heavenly spheres. Here his perspective merges with that of Chaucer, the Christian narrator, a religious conversion to accompany his epistemological one. He looks down from the heavens at the earth below him and despises its insignificance in respect to the pure happiness he now feels in heaven:

And down from thennes faste he gan avyse / This litel spot of erthe, that with the se / Embraced is, and fully gan despise / This wrecched world, and held al vanite / To respect of the pleyn felicite / That is in hevene above; and at the laste / There he was slayn, his lokyng down he caste. / And in himself he lough right at the wo / Of hem that wepten for his deth so faste; / And dampned al oure werk that foloweth so / The blynde lust, the which that may nat laste, / And sholden al oure herte on heven caste. (Robinson, 1957, p. 479)

This passage expresses the Christian Platonic epistemology, "contemptus mundi," and consolation. And yet there is pathos and irony in this "sub specie aeternitatis" vision that is missing in Macrobius and Chaucer's other source of inspiration, Boethius' Consolation of Philosophy. Troilus is irretrievably distanced, alienated from his earlier self and life. In his last glance downward he sees his own dead body on the field of battle surrounded by his weeping friends and laughs to himself at their sorrow, perhaps with pity for those mortals unable to conceive the "pleyn felicite" or pure happiness of heaven.

Boethius, whose Consolation of Philosophy Chaucer was translating at the time he wrote and incorporates into Troilus' speculations about foreknowledge and free will, offers a Troilus interesting epistemological analogue to the "sub specie aeternitatis" vision:

...Everything which is known is known not according to its own power but rather according to the capacity of the knower. Let me illustrate with a brief example: the roundness of a [ball] is known in one way by the sense of touch and in another by the sight. The sight, remaining at a distance, takes in the whole body at once by its reflected rays; but the touch makes direct contact with the sphere and comprehends it piecemeal by moving around its surface... The senses grasp the figure of the matter. Reason, on the other hand, goes beyond this and investigates by universal consideration the species itself which is in particular things. The vision of the intelligence is higher yet, and it goes beyond the bounds of the universe and sees with the clear eyes of the mind the pure form itself. (Boethius, 1962, pp. 110-111)

\section{Dante, Paradiso}

Although Chaucer alludes to Dante's Paradiso several times in Troilus and Criseyde, Troilus' "sub specie aeternitatis” vision resembles Macrobius' older version rather than Dante's most famous example of this trope in Paradiso xxxiii. There Dante ascends beyond the spheres of heavens into the Empyrean and sees God first as a ray of light Dante cannot turn his eyes from. In that absorbing alight of God's presence, Dante can see the entire universe as a simultaneous totality with its smallest parts and cosmic structure as an immediate spatial presence. Dante compares this vision of the universe to a book with its separate pages bound in one volume, perhaps also foreseeing the successful composition of the Divine Comedy itself:

O abounding grace, by which I dared to fix my look on the Eternal Light so long that I spent all my sight upon it! In its depth I saw that it contained, bound by love in one volume, that which is scattered in leaves though the universe, substances and accidents and their relations as it were fused together in such a way that what I tell of is a simple light. I think I saw the universal form of this complex, because in telling of it I feel my joy expand. (Sinclair, 1961, pp. 82-93) 
In one of the most amazing similes in the Divine Comedy Dante represents the temporal dimension of seeing the world from the perspective of eternity, the presence of all time, past, present, and future, as a single moment in eternity: "A single moment makes for me deeper oblivion than five and twenty centuries upon the enterprise that made Neptune wonder at the shadow of the Argo" (Sinclair, 1961, pp. 94-96). If all time is contained simultaneously in eternity, then one moment could easily contain everything that has happened in history for the twenty-five hundred years that had passed since the shadow of the Argo's sail startled Neptune to the moment Dante sees the vision. The conversion and consolation we have seen associated with the "sub specie aeternitatis” vision take cosmic form in Dante's vision. First his defects and limitations are transformed in the divine vision that fulfills and sustains them, gradually strengthening and perfecting his capacity to receive vision. The more he sees the more he is able to see:

Thus my mind, all rapt, was gazing, fixed, still and intent, and ever enkindled with gazing. At that light one becomes such that it is impossible for him to consent that he should turn from it to another sight; for the good which is the object of the will is all gathered in it, and apart from it that is defective which there is perfect. (Sinclair, 1961, pp. 100-105)

And finally, in a literally cosmic conversion and transformation, he feels his soul moving in harmony with the cosmos itself: "Here power failed the high fantasy; but now my desire and will, like a wheel that spins with even motion, were revolved by the Love that moves the sun and the other stars” (Sinclair, 1961, pp. 142-145).

\section{Borges, “El Aleph”}

Dante's "sub specie aeternitatis" vision invites consideration of the most famous contemporary version of this trope, Jorge Luis Borges’ parody of Dante in his story “The Aleph”. Borges' vision of the Aleph, a point in space at which all other points of the universe are simultaneously present, does not take place in heaven, however, but in the basement of a house on Garay Street in Buenos Aires: "In that single gigantic instant I saw millions of acts both delightful and awful; not one of them amazed me more than the fact that all of them occupied the same point in space, without overlapping or transparency” (Rodriguez Monegal, 1981, p. 161). As in Dante's vision, the Aleph, "the microcosm of the alchemists and Cabalists, our true proverbial friend, the multum in parvo" (Rodriguez Monegal, 1981, p. 160), appears to Borges as a "small iridescent sphere of almost unbearable brilliance” (Rodriguez Monegal, 1981, p. 161). But for Borges instead of consolation, his parody of a "sub specie aeternitatis" vision yields disillusionment or "desengano" and loss of identity in the infinite, impersonal nature of the vision. He sees not only the remains of his beloved Beatriz Viterbo in the Chacarita cemetery, but “unbelievable, obscene, detailed letters” (Rodriguez Monegal, 1981, p. 161) she had written his rival, Carlos Argentino Daneri. When Daneri asks Borges whether he saw the Aleph "really clear, in colors” (Rodriguez Monegal, 1981, p. 162), as if the vision were a film, Borges lies, denies he has seen anything at all, and encourages Daneri to have Beatriz Viterbo's family mansion demolished, thus destroying the Aleph.

\section{Cervantes, Don Quixote}

The “sub specie aeternitatis" trope in the conclusion of Cervantes’ Don Quixote is present by its deliberate omission, and yet performs the functions of epistemological conversion, transformation, and consolation. In Borges's “The Garden of Forking Paths” the sinologist Stephen Albert elucidates the chaotic Chinese novel of the same name as the story in words that echo the Negative Theology of Dionysius the Pseudo-Aereopagite: 
"In a riddle whose answer is chess, what is the only prohibited word?" I thought a moment and replied, "The word chess." "Precisely," said Albert. "The Garden of Forking Paths is an enormous riddle, or parable, whose theme is time; this recondite cause prohibits it mention. To omit a word always, to resort to inept metaphors and obvious periphrases, is perhaps the most emphatic way of stressing it”. (Borges, 1962, p. 27)

Cervantes's omission of the cosmic "sub specie aeternitatis" trope is such an omission, an omission that is part of Cervantes' realism, his suppression of metaphysics and the transcendent in his fiction if compared with his contemporaries, Spenser and Ariosto.

If we look at Don Quixote as a Menippean satire we see a collection of stories, his adventures on the road, the numerous tales and stories interpolated into the action, within the narrative frame of his wandering. The work could have been extended indefinitely. The second part of the novel is increasingly dark and depressing. Don Quixote never persuades Sancho to undergo the beatings that will disenchant Dulcinea and even suffers defeat at the hands of the Knight of the White Moon, his young neighbor from his village, Sanson Carrasco. Finally, Cervantes returns him to his home where he falls into depression and melancholy, develops a fever, sleeps for several hours, awakens a changed man, who now repudiates his books of chivalry and his identity as Don Quixote, and dies Alonso Quixano the Good. One brief sleep and Don Quixote passes from the perspectivism of the world of adventures on the road to an unambiguous reality, similar to that conversion we see Troilus make from the sorrow and despair of love to the pure felicity of heaven.

Cervantes marks the transition to a new perspective on reality in the opening sentence of the last chapter of the book by departing from his usual narrative point of view, down on the dusty roads of La Mancha, among Sancho and the knight, as if the reader were a participant and eye-witness in the every changing, temporal reality of the adventures. Instead the final chapter begins as if the reader himself is looking down at the action from a "sub specie aeternitatis" vision, a perspective that unfolds syntactically from the most universal down to the particular:

As all human things, especially the lives of men, are transitory, being ever on the decline from their beginnings till they reach their final end, and as Don Quixote had no privilege from Heaven exempting him from the common fate, his dissolution and end came when he least expected it. Whether that event was brought on by melancholy occasioned by the contemplation of his defeat or whether it was by divine ordination, a fever seized him and kept him in his bed for six days. (Cervantes, 1950, p. 934)

A doctor is called and advises the housekeeper and Sancho that Don Quixote should attend to the salvation of his soul since his body's salvation is in doubt:

It was the doctor's opinion that melancholy and despondency were bringing him to his end. Don Quixote begged to be left alone, for he wanted to sleep a little. They obeyed him, and he slept for more than six hours, at a stretch, as they say; so long, in fact, that his housekeeper and his niece thought he would pass away in his sleep. But at the end of that time he woke and cried out loudly: "Blessed be Almighty God, who has vouchsafed me this great blessing! ... My judgment is now clear and free from the misty shadows of ignorance with which my ill-starred and continuous reading of those detestable books of chivalry had obscured it”. (Cervantes, 1950, p. 935)

Don Quixote announces to his friends and Sancho: “Congratulate me, good sirs, for I am Don Quixote de la Mancha no longer, but Alonso Quixano, called for my way of life the Good” (Cervantes, 1950, p. 936).

A medieval narrative like Troilus or The Divine Comedy, Cervantes would have concluded Don Quixote's potentially unending series of adventures and suffering in the realm of experience by removing his protagonist from this world and ascending into heaven for the "sub specie aeternitatis" vision that would have converted 
time and the perspectivism of the world of appearance into eternity and true reality. But Cervantes' deliberate exclusion of transcendental reality and metaphysics prevents such an explicit conclusion. The effects of Don Quixote's brief sleep, however, exhibit the kind of conversion and transformation expected from the "sub specie aeternitatis" trope, a conversion from madness to sanity, from uncertainty to salvation. And yet this retraction of the fiction the reader has come to love and brought to life in his own reading is profoundly repugnant and disillusioning. This is Cervantes's very intention. As Borges points out in "Avatars of the Tortoise" every work of art requires a "visible unreality" to remind us that it is our own fabrication:

"The greatest magician (Novalis has memorably written) would be the one who would cast over himself a spell so complete that he would take his own phantasmagorias as autonomous appearances. Would not this be our case?” I conjecture that this is so. We (the undivided divinity operating within us) have dreamt the world. We have dreamt it as firm, mysterious, visible, ubiquitous in space and durable in time; but in its architecture we have allowed tenuous and eternal crevices of unreason which tell us it is false. (Borges, 1962, p. 208)

The conclusion of Don Quixote is such a “visible unreality." Cervantes does not want his fiction to assume an autonomous reality apart from his own novel. Cervantes in the role of Cide Hamete Benenjeli, the fictional chronicler of the novel, hangs up his pen at the end of the book and in the words attributed to the personified pen forbids the reader to continue the fiction on his own: "For me alone Don Quixote was born and I for him. His was the power of action, mine of writing” (Cervantes, 1950, p. 940). As we know, Cervantes' effort was futile. We have all become Don Quixote's as we read the novel and continue to mythologize him in the autonomous reality the legend of Don Quixote has assumed.

\section{Conclusion}

With Don Quixote and the dawn of the modern novel, perhaps the "sub specie aeternitatis" topos was bound for extinction, at least with its cosmological apparatus of heavenly spheres, but its effects remain whenever the encounters those moments in fiction that seem to convey the simultaneity of time and space that transform fiction and those who read it. "Sub specie aeternitatis" may appear for the last time in 1967 in the last pages of Gabriel Garcia Marquez's One Hundred Years of Solitude as Melquiades’ parchments are at last deciphered by the last Aureliano Buendia and disappear forever in the pages of the novel just read: "Melquiades had not put the events in the order of man's conventional time, but had concentrated a century of daily episodes in such a way that they coexisted in one instant” (Garcia Marquez, 1970, p. 382). This literary or fictional version of the "sub specie aeternitatis" vision brings revelation to the reader, but not consolation. For the final protagonist, Aureliano, it brings apocalyptic annihilation.

\section{References}

Boethius. (1962). The consolation of philosophy. (R. Green, Trans.). Indianapolis: Bobbs-Merrill.

Borges, J. L. (1962). Labyrinths: Selected stories and other writings. D. A. Yates \& J. E. Irby, (Eds.). New York: A New Directions Book.

Cervantes, M. S. (1950). The adventures of Don Quixote. (J. M. Cohen, Trans.). Baltimore: Penguin Books.

Garcia Marquez, G. (1970). One hundred years of solitude. (G. Rabassa, Trans.). New York: Avon.

Macrobius. (1952). Commentary on the dream of Scipio. (W. H. Stahl, Trans.). New York: Columbia University.

Robinson, F. N. (Ed.). (1957). The works of Geoffrey Chaucer. Boston: Houghton Mifflin.

Rodriguez-Monegal, E., \& Reid, A. (Eds.). (1981). Borges: A reader: A selection from the writings of Jorge Luis Borges. New York: Dutton.

Sinclair, J. D. (Trans.). (1961). The divine comedy of Dante Alighieri. III. Paradiso. New York: Oxford University Press. 